Avaliable online at:

http://www.syekhnurjati.ac.id/jurnal/index.php/ijas/index

DOI : https://dx.doi.org/10.24235/ijas.v1i2.4876

Published by Departement of Arabic Language and Literature, Faculty of Adab IAIN Syekh Nurjati Cirebon, Indonesia

\title{
Qasidah Burdah Imam Al-Busiri Dalam Pendekatan Jinas
}

Nur Huda

nurhuda.hasan27@gmail.com

STAI Al-Anwar Sarang Rembang

• Received: 31.07.2019 • Accepted: 18.10.2019 • Published online: 05.11.2019

Abstract: Qasidah, one of Arabic literary works that cannot be separated from the combination of the beauty of words and meanings contained therein. Qasidah Burdah Imam Al-Busiri work becomes the object of this research material for manifold beauty of poems and couplets presented. The approach used in this analysis is Jinas in balagah science, this is because Jinas is one of the theories for analyzing the beauty of words and meanings contained in poetry. While the method of analysis in this study uses the content analysis method. In general linguistic studies, Jinas is paired with the terms homonymy, homophony, and homograph. The analysis revealed the diversity of Jinas in Imam Al-Busiri's Qasidah Burdah by 172 species.

Keywords: jinas, qasidah burdah, imam al-busiri.

\section{Pendahuluan}

Qașidah merupakan salah satu istilah yang terkait erat dengan bait dalam ilmu 'Arūd dan Qawāfi. Nama lain dari bait (baca : al-Qāb) dilihat dari aspek jumlah atau hitungan terbagi menjadi empat. Pertama adalah Yatîm, yaitu bait dari sebuah syair yang hanya berjumlah satu baris. Kedua adalah Nutfah, yaitu bait yang berjumlah dua baris. Ketiga adalah Qit'ah, yaitu bait yang berjumlah 2 sampai dengan 6 baris. Keempat adalah Qașidah, yaitu kumpulan-kumpulan bait yang terdiri dari 7 baris atau lebih (Wāṣil, n.d.).

Diksi kata yang digunakan menjadi faktor keindahan yang dimiliki oleh kasidah tersebut. Hal ini terlihat dari kesamaan bunyi di setiap akhir bait. Di sisi lain, bahasa menjadi salah satu elemen penting dalam komunikasi antar peradaban dan kebudayaan di 
masyarakat. Sistem lambang bunyi arbitrer yang dimiliki bahasa akan digunakan oleh anggota masyarakat untuk bekerja sama, berinteraksi, dan mengidentifikasi diri (Sa'dudin \& Safitri, 2018) .

Qașidah yang dipilih sebagai objek material tulisan adalah qașidah Burdah karya imam al-Bușiri (1212-1301), ulama kenamaan abad 7 Hijriyah yang semasa dengan syeikh Izzuddin bin Abdussalam $(660 \mathrm{H})$, syeikh Abu Hasan al-Syażali $(656 \mathrm{H})$, dan Ibnu Ațā' al-Sakandārî (709 H). Alasan pemilihan qașidah ini adalah adanya berbagi macam keindahan syair dan bait yang disuguhkan oleh al-Busyiri dari aspek keindahan kata (Muhassināt al-Lafạiyyah) maupun makna (Muhassināt al-Ma'nawiyyah) yang tersebar di dalam burdahnya. Keindahan kata yang disuguhkan, dalam hal ini adalah Jinas, tidak hanya bersifat homogen dan tunggal.

Imam al-Bușiri memiliki nama lengkap Syarafuddin Abu Abdillah Muhmmad bin Sa'id bin Hammad bin Muhsin bin Abdullah bin Șanhaj bin Hilal al-Șanhaji al-Bușiri. Ia lahir pada hari Selasa 1 Syawal 608 H/1213 M di Dalaș, Maroko. Ia seorang keturunan Barber namum tumbuh besar di Bușir, desa terpencil di pinggiran sungai Nil, Mesir (Al-Adawi, 2010).

Al-Bușiri merupakan keturunan dua negara yang berbeda. Ayahnya berasal dari Maroko dan ibunya berasal dari Mesir. Pendidikan pertamanya diperoleh langsung dari ayahnya. Ia belajar ilmu agama dan mempelajari al-Quran bersama ayahnya. Setelah itu, ia pindah ke Kairo untuk belajar dan memperdalam ilmu keagamaan dan kesusastraan Arab dengan belajar langsung pada tokoh dan ulama kenamaan pada waktu itu. Di antaranya ia belajar dengan imam Abu Hayyan Asîiruddin Muhammad bin Yusuf al-Andalusi, Fathuddin Abu al-Fath Muhammad bin Muhammad al-'Umari alAndalusi, dan Ibnu Sayyidin Nas al-'Izz bin Jama'ah al-Kanani alHamawi. Dengan merekalah al-Buṣiri mendapatkan gemblengan untuk menjadi sastrawan yang handal pada masanya (Amsir, 2010).

Sebuah sumber menyatakan bahwa awal mula qașîdah Burdah dibuat ketika al-Bușiri sedang mengalami penyakit lumpuh yang dikenal dengan Hemiplegia, dalam bahasa Arab dikenal dengan Fālij. 
Beberapa dokter telah berusaha mengobati dan menyembuhkannya. Namun apa daya, penyakit yang dideritanya tak kunjung membaik. Bahkan dokter telah memfonis bahwa penyakit yang dideritanya sudah tidak akan mampu lagi untuk disembuhkan. Keadaan yang dialaminya cukup lama, sehingga sangat wajar ketika ia dihampiri rasa keputusasaan. Di ambang keputusasaan tersebut ia berniat untuk menggubah syair-syair pujian dan penghormatan terhadap nabi Muhammad dengan harapan nantinya akan diberi syafaat kesembuhan melalui (wasilah) syair-syair tersebut (Adib, 2009).

Qasidah Burdah karya Imam Al-Busiri terdiri dari 10 bab dan setiap bab mempunyai judul yang berbeda. Sebagai contoh bait pertama dari bab pertama yang berbunyi

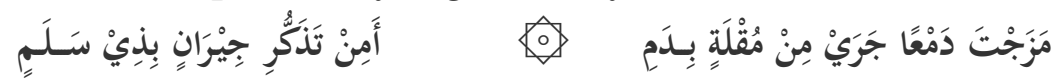

“Apakah karena mengingat para kekasih di Dzi Salam sana. Engkau deraikan air mata dengan darah duka."

Bait di atas ditinjau dari teori jima yang ada dalam disiplin ilmu balaghah (ilmu badi') mengandung Jinās Nāqis atau Jinās Muẓ̂ll. Hal tersebut karena pada bait tersebut ada dua kata yang sama, namun berbeda jumlah hurufnya. Keduanya adalah kata (دَمْعًا) dan kata (בَ) • •

Berdasarkan paparan di atas, perlu adanya kajian dan analisa terhadap kasidah burdah karya Imam al- Busiri dengan pendekatan teori jinas untuk mengungkap keindahan bahasa secara lafdi dan makna.

\section{Metode}

Penelitian ini menggunakan metode deskriptif analisis. Metode ini digunakan untuk mendeskripsikan data-data penelitian yang kemudian akan dianalisis dengan pendekatan teori jima. Metode deskriptif analisis akan memberikan pemahaman dan penjelasan secukupnya. Kemudian, metode ini digunakan untuk mendeskripsikan dan menganalisis jenis jinas yang terdapat dalam Qasidah Burdah. 


\section{Hasil dan Pembahasan}

\section{a. Imam Al-Busiri}

Gubahan syair yang dibuat oleh al-Busîiri dinamai dengan alKawākib al-Durriyyah fî Madhi Khair al-Bariyyah (Gemerlap Bintangbintang dalam Senandung Pujian Terhadap Manusia Terbaik). Namun demikian, gubahan dan karya tersebut lebih dikenal oleh dunia dengan Burdah. Hal itu dikarenakan adanya berita mimpi yang sudah tersebar sedemikian luasnya, maka nama "Burdah" itu kemudian menjadi identitas bagi syair tersebut dan menjadi lebih populer dari pada nama aslinya (Adib, 2009).

Sebagian ulama berpendapat bahwa penamaan dan penisbatan burdah lebih layak diberikan kepada sahabat Ka'ab bin Zuhair (W. 662), seorang penyair kenamaan yang baru masuk Islam yang telah menggubah syair pujian dan penghormatan pada Nabi dalam qașîdah Banat Su'ād. Sementara qașîdah al-Bușîri lebih tepat dinamakan dengan qașîdah Bara'ah karena ia telah terbebas dari penyakit lumpuhnya (Adib, 2009).

Beberapa karya yang digubah oleh al-Buṣîni adalah sebagai berikut :

1. Al-Kawākib al-Durriyyah fì Madhi Khair al-Bariyyah, dikenal luas dengan nama "Burdah" dan menjadi topik pembahasan pada tulisan ini.

2. Al-Qașîdah al-Muhammadiyyah, terdiri dari 16 bait. Syair tersebut sering dibacakan pada majlis-majlis shalawat yang semakin semarak dan tersebar di pelosok-pelosok negeri.

3. Al-Hamziyyah fì al-Madāih an-Nabawiyyah, terdiri dari 427 bait dan dianggap sebagai karya sastra terbesar imam al-Buṣ̂ri.

4. Żakkir al-Ma'àd fì Wazni Banat Su'àd, terdiri dari 204 bait yang merupakan gubahan syair pembanding bagi Banat Su'ād, sebuah karya populer yang digubah oleh Ka'ab bib Zuhair yang menjadi pelopor syair pujian dan penghormtan pada Nabi Muhammad saw.

5. Al-Qașîdah al-Mudhāriyyah fi al-Ṣolāh 'alā Khoir al-Bariyyah, berjumlah 41 bait. 
6. Hukmul Hawā, berjumlah 30 bait yang memuat tentang bahaya akan ahawa nafsu (Adib, 2009).

Di atas merupakan karya-karya gubahan syair yang bermuatan pujian dan penghormatan pada nabi Muhammad saw. sementara karya lain yang bersifat umum adalah sebagai berikut :

1. Katab al-Masyib, gubahan syair ini berjumlah 141 bait yang berisikan tentang ekspresi kekaguman al-Bușîri kepada guru spiritualnya. Mereka adalah syeikh Abul Hasan al-Syażili dan syeikh Abul Abbas al-Mursi. Merekalah yang mengajarinya tentang ketauhidan.

2. Asy ba'da al-Maut, hanya berjumlah empat bait yang berisikan tentang kegelisahan tentang adanya berita dan isu bahwa ia telah meninggal dunia.

3. Mustakhdimîn wa Syayāțîn, syair ini juga hanya berjumlah empat bait yang berisi tentang hilangnya keledai kesayangannya.

4. Faḍluk Awwal,syair ini memuat sekitar 150 bait yang berisi tentang kekagumannya pada penguasa pada waktu itu yang bernama al-Izz yang telah mencapai masa kegemilangan dan keemasaan dalam bidang pendidikan. Syair ini dibuat ketika al-Buṣ̂ri berusia sekitar 25-an (Adib, 2009).

Imam al-Busiri menggubah syair kasidah burdah ketika sedang mengalami lumpuh. Di tengah kondisi lumpuh yang dialaminya, ia tetap bersikukuh untuk merealisasikan niatannya dalam menggubah syair tersebut. Hal itu dikarenakan bahwa ia meyakini dengan seyakin-yakinnya bahwa melalui syair pujian dan penghormatannya tersebut penyakit lumpuhnya dapat disembuhkan. Di tengah-tengah pembaringannya, ia mulai menggubah syair. Dari kata demi kata, kalimat demi kalimat, dan demi bait demi bait syair itu disusun beberapa bulan, dengan penuh kesabaran dan kekhusyu'an gubahan syair itu akhirnya selesai. Beberapa waktu setelah penyelesaian syair tersebut, pada suatu malam ia bermimpi ditemui oleh baginda nabi Muhammad saw. Dalam mimpi tersebut nabi mengusap umbunumbunnya dan menyelimuti tubuhnya dengan Burdah (baju hangat 
yang terbuat dari kulit binatang) yang biasa dipakai oleh nabi. Sungguh ajaib, tak lama kemudian al-Bușiri sembuh total dari penyakitnya (Adib, 2009).

Ada riwayat lain yang tak jauh berbeda dengan sebelumnya, sebagaimana yang disampaikan oleh syeikh al-Bajuri bahwa ketika alBușiri telah sampai pada bait yang ke-52 yang berbunyi :

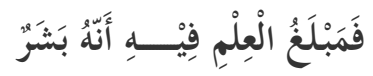

Artinya :"Puncak Pengetahuan tentang dirinya (Rasulullah saw.), bahwa dirinya adalah manusia biasa", tangan al-Buṣîri berhenti kaku dan tak bisa melanjutkan syairnya karena ia merasa sū'ul adāb dalam pengungkapan syair tersebut. Malam harinya ketika ia tertidur, ia bermimpi ditemui Rasulullah saw. Dalam mimpinya Nabi berkata "Teruskan!", al-Busîiri menjawab "aku tak mampu", Nabi berkata lagi "Teruskan!", al-Busîiri menjawab "aku tak mampu wahai Nabi", kemudian nabi membantu dalam menyempurnakan bait tersebut dengan kalimat :

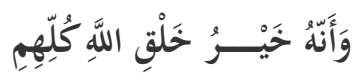

Artinya "Dan sesungguhnya beliau sebaik-baik makhluk Alloh Swt, semua tanpa terkecuali".

dari sanalah kemudian penggubahan bait tersebut menjadi sempurnya. Hingga pada akhirnya setelah beberapa bulan al-Busîiri berhasil menyelesaikan gubahan syair tersebut. Setelah itu, ia senantiasa menyenandungkan bait-bait tersebut dengan harapan dapat terlepas dan sembuh dari penyakit lumpuh yang dideritanya. Sementara dokter telah memvonis bahwa penyakitnya tak lagi bisa disembuhkan. Akhirnya pada suatu malam al-Busîiri bermimpi ditemui dan didatngi oleh Nabi. Dalam mimpinya tersebut, Nabi mengusapkan tangan beliau pada bagian tubuh al-Busiri yang sakit dan menyelimutinya dengan Burdah (di antara artinya adalah surban, mantel, baju hangat yang terbuat dari kulit rusa). Maka seketika penyakitnya menjadi sembuh total (Al-Bajuri, 2009).

Setelah kejadian tersebut, keesokan harinya al-Busîîi keluar rumah. Di tengah-tengah perjalanan ia berjumpa dengan pemuda 
saleh yang langsung menyapa dan meminta al-Busîiri supaya menyenandungkan bait-bait qasî̀dah yang telah digubahnya. AlBusîri merasa heran dan bertanya-tanya, dari mana orang tersebut tau kabar penggubahan syair dan mimpi itu. Dan di akhir pembicaraan mereka, pemuda tersebut mengatakan bahwa ia telah mendapati imam al-Busîiri berhadap-hadapan dengan Rasulullah saw. seraya membacakan gubahan syairnya, dalam mimpi. Pemuda itu berkata "dan setelah engkau membacanya, aku melihat engkau dihadiahi Burdah oleh Rasulullah saw" (Al-Adawi, 2010).

\section{b. Qasidah Burdah dalam kajian al-Jinas}

Sejarah kesusastraan mencatat bahwa peletak dasar tipologi ilmu Balagah menjadi tiga bagian (Bayān-Ma'ani-Badî) adalah Abu Ya'qūb Yusuf al-Sakkāki (656 H.). Namun demikian, seiring dengan maju dan berkembangnya zaman, tipologi ilmu Balagah yang dibagi menjadi tiga di atas berubah menjadi pengkajian secara spesifik dan independen karena begitu luasnya penejlasan dan penjabaran masing-masing bagiannya. Proses independensi ilmu Balagah ini dipelopori oleh Badru al-Din Bin Malik al-Jayani (686 H.).

Jinās merupakan salah satu cabang ilmu Badî yang termasuk dalam kajian Muḥassināt al-Lafạiyyah (cara memperindah bahasa pada tataran kata). Sementara Muhassināt al-Ma'nawiyyah tidak menjadi penrhatian dalan tulisan ini. Al-Hasyimi dalam bukunya mengatakan bahwa setidaknya terdapat tidak kurang 23 pembahasan dalam kategori Muhassināt al-Lafạiyyah. Diantaranya adalah Jinās, Iqtibās, Saj', dan lain-lain (Al-Hasyim, 1994).

Secara etimologi, Jinās merupakan derivasi dari kata Jā-na-sa, yu$j \bar{a}-n i-s u, \quad m u-j \bar{a}-n a-s a-t a n$ yang artinya menyerupai dan menyatu bersamanya dalam satu bentuk (Ahmad Handawi Hilal, 2002 : 12). Sementara Jinās secara terminologi adalah Tasyābuh al-Lafẓaini fî alKitābati wa Ikhtilāfuhumā fî al-Ma'nā, dua kata yang serupa dan artinya berbeda.

Jinās dalam kajian Linguistik Umum disejajarkan dengan istilah Homonim. Abdul Chaer menjelaskan bahwa homonim merupakan dua buah kata atau satuan ujaran yang yang bentuknya sama namun Indonesian Journal of Arabic Studies, Volume (1), Issue (1), November 2019 
maknanya berbeda. Ada juga dua istilah lain yang hampir semakna dengan homonim. Mereka adalah homofon dan homograf. Homofon merupakan kesamaan bunyi dua satuan ujaran tanpa memeprhatikan ejaan, apakah sama ejaannya ataukah tidak. Sementara homograf mengacu pada bentuk ujaran yang sama ortografinya atau ejaannya namun berbeda ucapan dan maknanya (Chaer, 2007).

Secara umum, menurut para ahli Balagah, Jinās terbagi menjadi dua : 1) Jinās Tām, yaitu apabila terdapat dua lafaz atau kata yang memiliki kesamaan dalam empat unsur; Nau'al-Khurūf (jenis huruf), Syak al-Khurūf (syakal/harakat), 'Adad al-Khurūf (jumlah), Tartîb alKhurūf (urutan); 2) Jinās Gairu Tām, yaitu apabila terdapat perbedaan di antara kedua kata tersebut pada salah satu dari empat unsur yang terdapat dalam Jinās Tām (Al-Hasyim, 1994).

Dari seluruh bait dalam Qasidah Burdah Imam al-Busiri, terdapat beberapa bait yang mengandung unsur jinas. Di sini, secara terperinci peneliti akan mencoba untuk mengurai dan menganalsis pada masing-masing bait yang terdapat Jinās-nya.

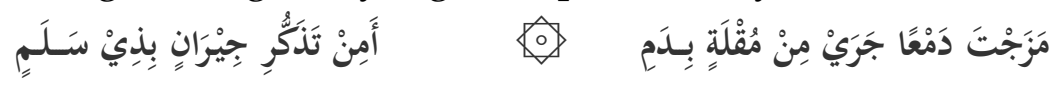

(Apakah karena mengingat para kekasih di Dzi Salam sana.

Engkau deraikan air mata dengan darah duka.)

Pada bait di atas terdapat Jinās Nāqis atau Jinās Muẓ̂l, yaitu adanya dua kata yang sama, namun berbeda jumlah hurufnya.

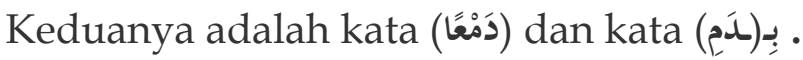

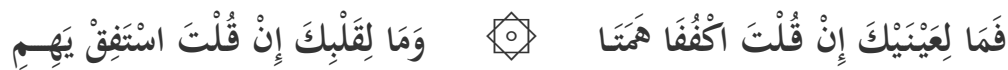

(Mengapa kedua air matamu tetap meneteskan air mata? Padahal engkau telah berusaha membendungnya. Apa yang terjadi dengan

hatimu? Padahal engkau telah berusaha menghiburnya).

Pada bait tersebut terdapat Jinas Istiqāq yang berada pada kata

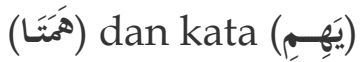

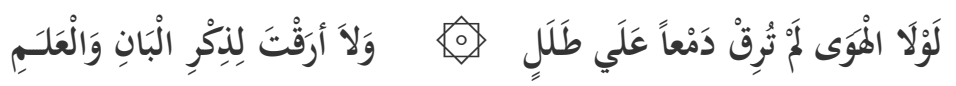




\section{Nur Huda}

(Andaikan tak ada cinta yang menggores kalbu, tak mungkin engkau mencucurkan air matamu. Meratapi puing-puing kenangan masa lalu

berjaga mengenang pohon ban dan gunung yang kau rindu)

Terdapat Jinas Isytiqaq pada kata (تُقُقِ) dan kata (أرَقْتَ).

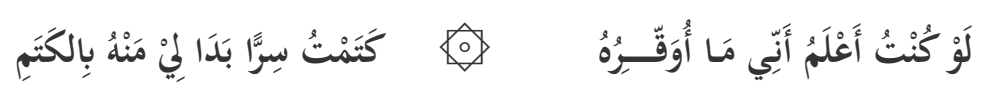

(Jikalau aku tahu bahwa diriku tak mampu menghormat tamu Maka lebih baik kusembunyikan diriku dengan cara menyemir uban dikepalaku)

Pada bait tersebut terdapat Jinas al-Muharraf yaitu pada kata (كَتَمْتُ) dan kata (بالكَتَمِ).

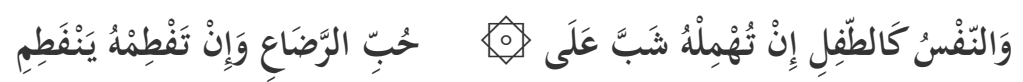

(Nafsu bagaikan bayi, bila kau biarkan akan tetap suka menyusu.

Namun bila kau sapih, maka bayi akan berhenti sendiri)

Pada bait tersebut terdapat Jinas al-Isytiqaq pada kata (تَفْطْمْ dan kata (يَنْفَطِ).

$$
\text { فَاَصْرِفْ هَوَاهَا وَحَاذِرْ أَنْ تُوَلِيَهُ }
$$

(Maka palingkanlah nafsumu, takutlah jangan sampai ia menguasainya

Sesungguhnya nafsu, jikalau berkuasa maka akan membunuhmu dan membuatmu tercela)

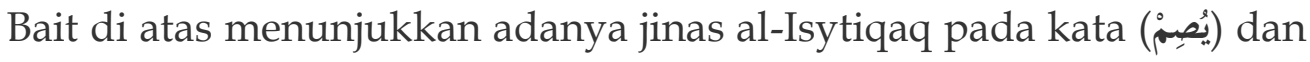
kata (يَصِ).

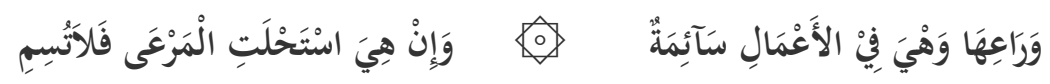

(Dan gembalakanlah nafsu, karena dalam amal nafsu bagaikan hewan ternak.

Jika nafsu merasa nyaman dalam kebaikan, maka tetap jaga dan

$$
\text { jangan kau lengah) }
$$

Pada bait tersebut ditemukan Jinas al-Isytiqaq pada kata (رَاعِهَا) dan kata (الْمَزعَىَ). 


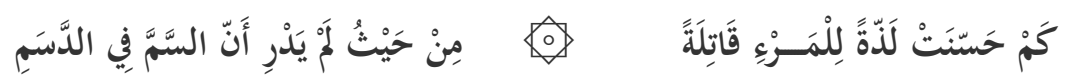

(Betapa banyak kelezatan, justru bagi seseorang membawa kematian Karena tanpa diketahui, adanya racun tersimpan dalam makanan)

Pada bait di atas terdapat Jinas Naqis pada kata (السَّمَ) dan kata (الدََّسَ).

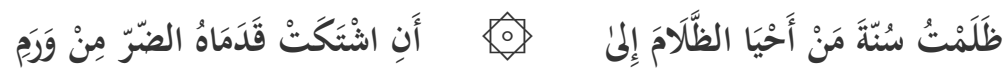

(Kutinggalkan sunna nabi, yang selalu beribadah menghidupkan gulita malam

Hingga telapak kaki sakit, membengkak karena ibadah malam)

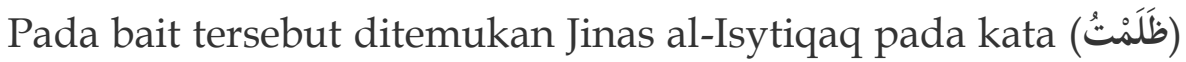
dan kata (الظَََّمَ).

$$
\text { وَرَاوَدَتْهُ الجُبَبَالُ الشُّمْ مِنْ ذَهَبٍ }
$$

(Nabi yang ditawarkan gunun emas menjulang tinggi

Namun beliau tolak, dengan bangga perasaan hati)

Pada bait di atas didapati Jinas al-Isytiqaq pada kata (الشُّمّ) dan dan

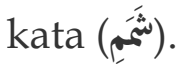

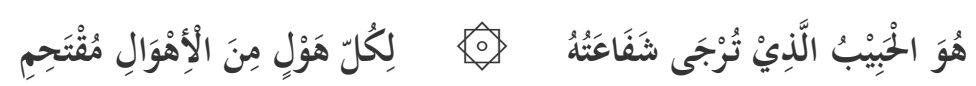

(Beliau kekasih Allah ta'ala, yang diharapkan oleh semua

$$
\text { insan syafa'atnya }
$$

Dari tiap perkara yang menakutkan yang datang mencekam)

Pada bait di atas terdapat Jinas Naqis atau Jinas Gairu Tam

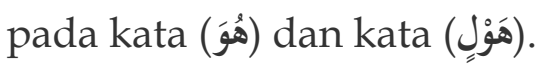

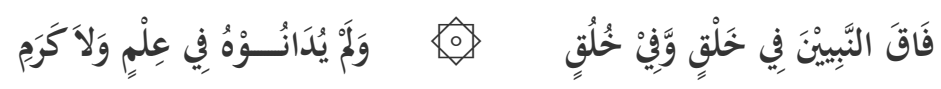

(Beliau melampaui para nabi-nabi terdahulu baik ketampanan ataupun akhlak budi pekerti. Mereka para nabi-nabi terdahulu takkan menyamai Rosululloh Saw, baik dalam ilmu atau kemulian-Nya) Pada bait tersebut terdapat Jinas Musahhaf pada kata (خَلَقِ) dan kata (خُلْقِ). 
Nur Huda

$$
\text { نَ مَوْلِدُهُ عَنْ طِيْـب عُنْصُرِهِ }
$$

(Kelahiran sang nabi menampakkan kesucian diri

Alangkah indah permulaannya, juga indah penghabisannya)

Pada bait tersebut terdapat Jinas Mumāsil pada kata (طِيْـبِ) dan kata (طِيْبَ).

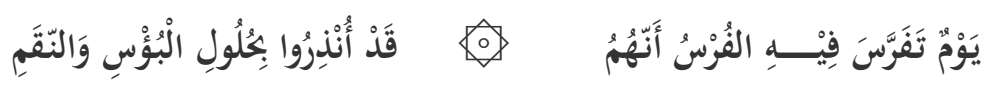

(Hari kelahiran Rosululloh saat ada firasat bangsa persia Bahwa ada peringatan kepada mereka datangnya bencana dan siksa) Pada bait tersebut terdapat Jinas al-Isytiqaq pada kata (تَفَََّّ) dan kata (الفُرُْسُ).

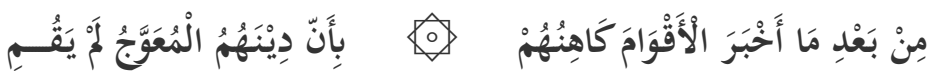

(Para rahib mereka telah kabarkan berita

Bahwa agama mereka melenceng, dan tak kan bertahan lama)

Pada bait tersebut terdapat Jinas al-Isytiqaqa pada kata (الْأَفْوَامَ) dan

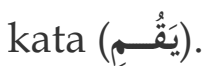

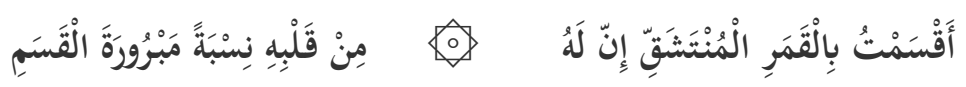

(Aku bersumpah demi penguasa rembulan nan pecah

Sesungguhnya hati nabi nan terbelah bak bulan yang dibelah)

Pada bait tersebut terdapat Jinas al-Isytiqaq pada kata (أَقَْْْْتُُ) dan kata (ألََْسَمِ).

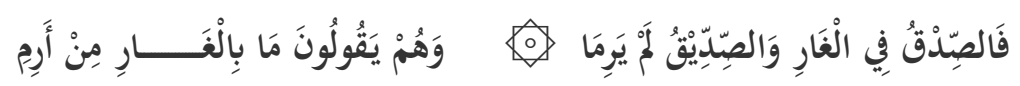

(Nabi dan Abu Bakar As-Siddiq keduanya berada dalam gua

Mereka orang-orang kafir berkata tak seorang pun dalam gua)

Pada bait tersebut terdapat jenis al-Isytiqaqa pada kata (الصِّدُقُ) dan kata (الصِّدِيْقِقِ).

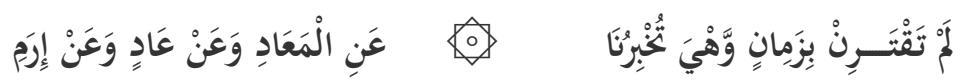

(Ayat - ayat al-quran tak bersamaan denga zaman 
Dan ayat-ayat Al-Qur'an telah kabarkan pada kita tentang akhirat, kaum `Ãd dan kota iram)

Pada bait tersebut terdapat Jinas Muṭarraf pada kata (الَْمَعَدِ) dan kata (عَادٍ)

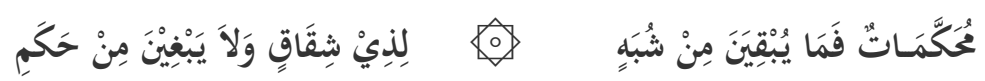

(Sungguh kokoh itu al-quran tak tinggalkan keserupaan

Bagi yang punya perselisihan dan tak usah cari hakim kebenaran)

Pada bait tersebut terdapat Jinas al-Isytiqaq pda kata (عُكَكََّاتُ kata (حَكَ).

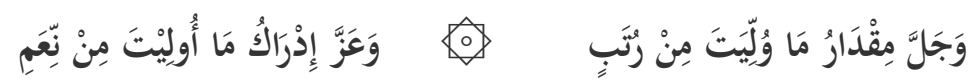

(Sungguh agung nilainya derajat yang kau dapati

Sungguh jarang lagi langka dapatkan nikmat yang engkau diberi)

Pada bait tersebut terdapat Jinas al-Isytiqaq pada kata (وُلَّلّيَتَ) dan kata (أُوِْيْتَ).

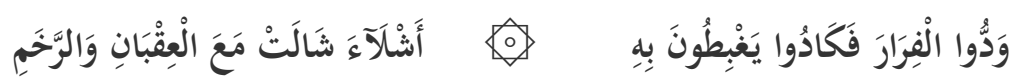

(Mereka ingin lari hampir saja mereka berharap diri

Anggota badan nan hancur menjauhi, terbang bersama burung rakhmah dan rajawali)

Pada bait tersebut terdapat Jinas al-Isytiqaq pada kata (أَنْلَكَ) dan kata (نَالَتْنْ).

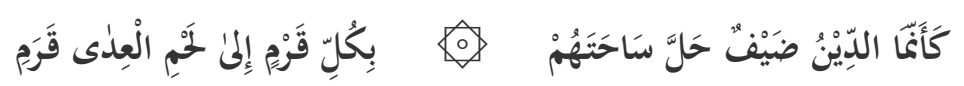

(Islam datang bagai tamu undangan, singgah di halaman sahabat nabi

Bersama orang-orang jantan yang sangat ingin membunuh musuh islami)

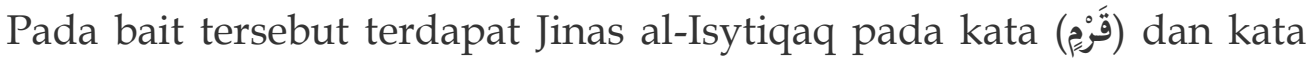
(قَرَ).

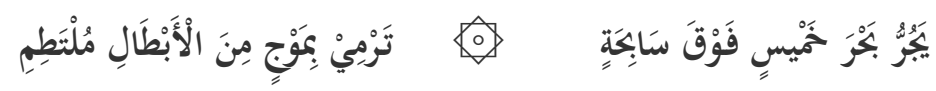

(Ia membawa lautan pasukan diatas kuda yang berenang jaya 


\section{Nur Huda}

Membawa para pemberani lagi jantan bagai debur ombak samudera)

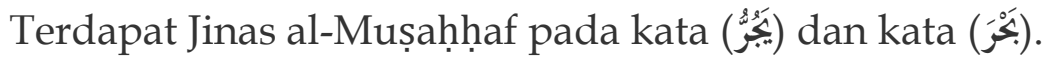

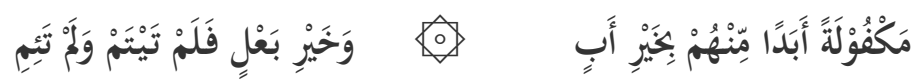

(Islam terjamin selamanya dari mereka dengan sebaik-baik aba

Dan sebaik-baik suami tercinta mereka takkan jadi yatim dan janda)

Pada bait di atas terdapat Jinas al-Isytiqaq pada kata (تَيَتَمْ) dan kata (تَئمِ(n).

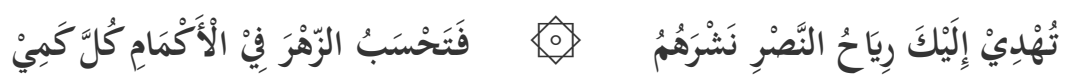

(Angin kemenangan kirimkan padamu semerbak keharuman tentara

Hingga bunga di kelopak tersangka olehmu tentara nan gagah perkasa)

Pada bait tersebut terdapat Jinas al-Lāhiq pada kata (النَّصْرِ) dan kata (نَشْرَ).

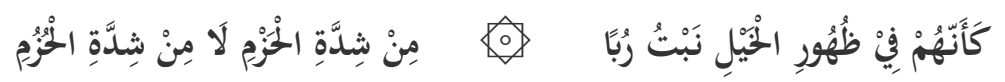

(Seakan-akan mereka dipunggung kuda laksana pepohonan di bukit tinggi

Karena kuatnya kemantapan belaka bukan karena kuatnya tali).

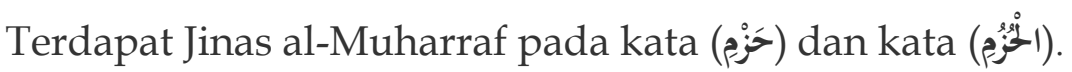

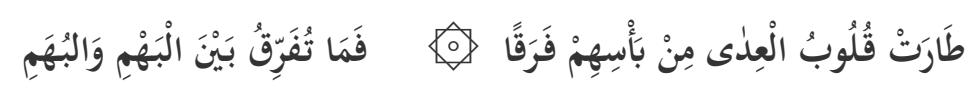

(Hati para musuh goncang duka karena takut serangan dahsyat para ksatria

Maka tak dapat bedakan antara kumpulan anak domba dan sekelompok pemberani perkasa)

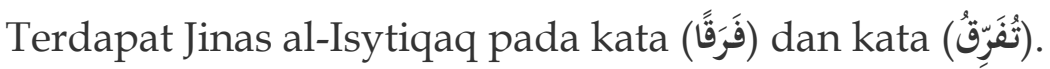

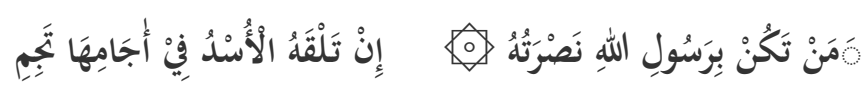

(Barangsiapa meraih kemenangan sebab rasulullah nabi pilihan Bila singa di rimba menjumpainya, maka akan diam tunduk padanya) 
Pada bait tersebut terdapat Jinas al-Isytiqaq pada kata (أُجَاِم) dan kata (تَّ).

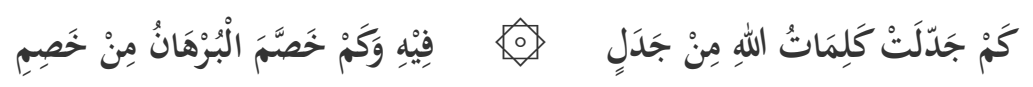

(Seringkali kitab suci al-quran jatuhkan musuh dalam perdebatan

Dan telah banyak dalil - dalil pasti kalahkan musuh - musuh sejati)

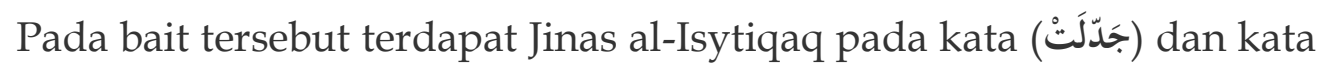
(جَدَ)

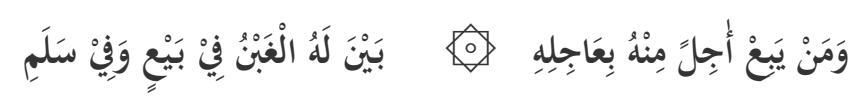

(Barangsiapa menjual akhirat dengan dunia kebahagian sesaat

Maka nyata baginya kerugian dalam jual beli dan akad salam)

Pada bait tersebut terdapat Jinas Muḍari' pada kata (أُجِلَ) dan kata

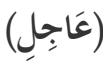

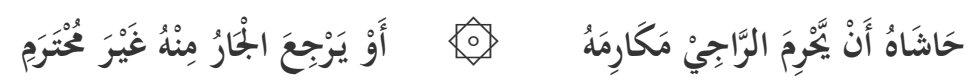

(Maha suci Allah ta`ala nabi tak tolak pengharap syafaatnya

Atau tetangga kembali darinya tanpa dihormati dan dimuliakan)

Pada bait tersebut terdapat Jinas al-Isytiqaq pada kata (يََّّْرَ) dan kata (مُعَْرَ).

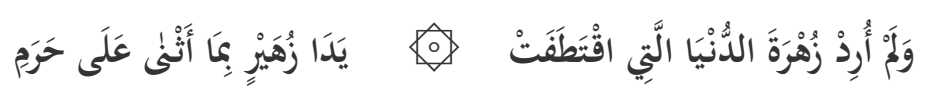

(Aku tidaklah mengharapkan dunia yang penuh kenikmatan Seperti yang zuhair petik dengan tangannya atas raja haram yang ia puja)

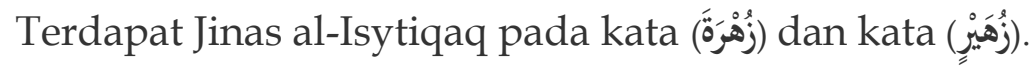

\section{Simpulan}

Teori Jinas merupakan cabang atau bagian dari Muhassināt alLafziyyah yang menjadi bagian tak terpeisahkan dari ilmu Badî. Selain Muhassināt al-Lafạiyyah, ilmu Badi juga mejelaskan bagaimana tantang bagiamana membuat dan memperindah bahsa melaui maknanya yang dikenal dengan Muhassināt al-Ma'nawiyyah. 
Pada dasarnya, Jinas terbagi menjadi dua, yaitu Jinas Tām dan Jinas Gairu Tām. Namun, jika dikembangkan lebih cermat dan detail, Jinas terbagi emnjadi ebebrapa kelompok, diantaranya adalah Jinās Mumāsill, Jinās Mustaufî̀, Jinās Isytiqāq, Jinās Murokkab, Jinās Muḍāri', Jinās Lāhị, Jinās Nāqis, Jinās Muharraf, Jinās al-Qolb, Jinās al-Muzdawij, Jinās al-Tașhîff/al-Mușaḥhaf.

Pada Qașîdah Burdah ditemukan beberapa bentuk atau macammacam Jinas yang tersebar pada bait-baitnya. Namun demikian, dari 172 bait yang ada, Jinas al-Isytiqāq lebih dominan keberadaannya dibandingkan dengan Jinas lainnya. 20 Jinas al-Isytiqaq tersebar di berbagai bait Burdah imam al-Busiri. Sementara Jinas yang lainnya, masing-masing untuk Jinas Naqis, Jinas Muzil, dan Jinas Musahhaf adalah 2 (dua). Sementara untuk Jinās Mumāsill, Jinās Muḍāri', Jinās Lāhiq, dan Jinās Muharraf masing-masing mendaptakan satu porsi pada bait Burdah tersebut.

\section{Referensi}

Adib, M. (2009). Burdah; Antara Kasidah, Mistis \& Sejarah. Yogyakarta: Pustaka Pesantren.

Al-Adawi, H. (2010). Syarh al-Burdah al Busiriyyah. Lebanon: Darul Kutub al-Ilmiyyah.

Al-Bajuri, I. (2009). Syair-syair Burdah dalam Hasyiah al-Bajur. Surabaya: Mutiara Ilmu.

Al-Hasyim, A. (1994). Jawahir al-Balagah. Lebanon: Baerut.

Amsir, S. (2010). Qashidah Al-Bardah. alKisah.

Chaer, A. (2007). Linguistik Umum. Jakarta: Rineka CIpta.

Sa'dudin, I., \& Safitri, E. (2018). Keragaman Jinas dalam Kitab Marqotul Mahabbah Karya Syekh Abdul Majid. LISANAN ARABIYA: Jurnal Pendidikan Bahasa Arab, 2(01), 57-77.

Wāṣil, S. (n.d.). Mausū'ah al-'Arūd wa al-Qäfiyah. 